\author{
Тарасова E.B. \\ кандидат економічних наук, доцент \\ кафедра обліку та аудиту \\ Одеська національна академія харчових технологій \\ вул. Канатна, 112, м. Одеса, Україна, 65039 \\ E-mail: tarasova2k@yandex.ua
}

\title{
ФІНАНСОВИЙ МЕХАНІЗМ СТІЙКОГО РОЗВИТКУ ПІДПРИЄМСТВА
}

У статті досліджується роль фрінансового механізму забезпечення стійкого розвитку підприємства, обґрунтовується необхідність забезпечення збалансованості між цілями підприємства й умовами зовнішнього і внутрішнього середовища. Визначено складові підсистеми фінансового механізму, що забезпечують стійкий розвиток підприємства. Розглянуто існуючі методологічні підходи до організації фінансів. Пропонується розширити концептуальний підхід до визначення фінансового механізму за рахунок включення комплексного, програмно-цільового та критеріального підходів.

Ключові слова: фрінансовий механізм; фрінансова стійкість; фрінансові важелі; фрінансові відносини; фрінансові методи.

\section{This work is licensed under a Creative Commons Attribution 4.0 International License} http://creativecommons.org/licenses/by/4.0/

Постановка проблеми та її зв'язок з важливими науковими та практичними завданнями. Однією з характеристик стабільного стану підприємства $є$ його фінансова стійкість. Забезпечення фінансової стійкості підприємства в значній мірі залежить від ефективності його фінансового механізму. Невизначеність загальноекономічної ситуації, зміни законодавчої системи негативно впливають на прибутковість підприємств та призводять до збільшення ризику неефективності їх діяльності. За цих умов важливим завданням кожного підприємства є адаптація до нестабільного ринкового середовища, до постійних змін ринкової кон'юнктури. Це вимагає формування фінансового механізму забезпечення стійкого розвитку підприємств.

Розуміння фінансово-економічної стійкості у стабільних умовах функціонування та в умовах кризи буде різним. Цільовою спрямованістю підприємств, що працюють у кризових умовах, стає не ефективне використання ресурсів і навіть не отримання максимального фінансового результату, а забезпечення збалансованості між цілями підприємства й умовами зовнішнього і внутрішнього середовища. Ця збалансованість характеризується певними значеннями показників фінансового стану підприємства та знаходиться в залежності від сукупності чинників середовища, що його оточує. Актуальність дослідження фінансового механізму забезпечення стійкості зумовлена об'єктивною потребою підприємств промисловості в поліпшенні показників фінансовогосподарської діяльності та накопиченні потенціалу їх подальшого розвитку.

Аналіз останніх публікацій 3 проблеми. Дослідження теоретичних та практичних аспектів функціонування фінансового механізму на макро- та мікрорівні відображені в працях вітчизняних і зару - біжних вчених М. Артуса, І. Балабанова, В. Буряковського, О. Ковалюка, Л. Костирко, М. Крупки, В. Москаленка, В. Опаріна, І. Плікуса, А. Поддєрьогіна, А. Шеремета та ін. Разом з цим, високо оцінюючи результати цих досліджень, слід констатувати, що проблеми формування фінансового механізму управління стійким розвитком підприємств досліджені недостатньо. Тому існує об'єктивна необхідність обгрунтування методів та інструментів реалізації фінансового механізму управління фінансовою стійкістю підприємства.

Формулювання цілей дослідження. Метою статті є дослідження складових підсистем фінансового механізму, що забезпечують стійкий розвиток підприємства.

Виклад основних результатів та їх обгрунтування. У процесі господарювання фінанси промислових підприємств здійснюють свої функції переважно через фінансовий механізм, під яким розуміється оформлена законодавчими й нормативними актами взаємозалежна система заходів, спрямованих на використання об'єктивно існуючих грошових відносин для досягнення цілей підприємства.

Таким чином, якщо фінанси - об'єктивна економічна категорія, що відображає об'єктивно існуючі грошові відносини, то фінансовий механізм це система управління фінансами, або спосіб впливу на фінансові відносини через фінансові важелі за допомогою фінансових методів [4].

Фінансовий механізм має дві взаємопов'язані сторони: суб'єктивну й об'єктивну. Об'єктивна сторона фінансового механізму виявляється в тому, що він будується відповідно до вимог об'єктивних економічних законів. 3 іншого боку, фінансовий механізм носить суб'єктивний характер, тому що 
встановлюється вищим менеджментом підприємства для вирішення завдань, що стоять перед ним на тому або іншому етапі розвитку.

Узагальнення існуючих методологічних підходів до організації фінансів у вітчизняній науці дозволило виявити, що управління фінансами суб'єктів господарювання можна здійснювати на основі процесного та системного підходів. Процесний підхід полягає у використанні сукупності форм, методів, прийомів управління рухом фінансових ресурсів. Системний підхід - це частина загальної системи управління, основним завданням якої є реалізація управлінського впливу на рух фінансових ресурсів з метою підвищення ефективності їх розподілу та використання. Саме останній є більш доречним у відповідності до принципів функціонування в умовах ринкового господарства. Впровадження системного підходу управління процесом збалансування фінансів підприємства на усіх фазах їх кругообігу вимагає визначення структури системи (окремих елементів та їх функцій), комунікацій (інформаційних зв'язків), функціональності (механізму реалізації).

Таким чином, можна узагальнити, що відповідно процесному підходу під фінансовим механізмом розуміють функціонування безпосередньо фінансів підприємств. Матеріальним відображенням фінансових відносин є грошові потоки, організація яких відбувається за певними правилами. На підставі даного підходу і формується розуміння фінансового механізму як організаційного відображення фінансових відносин. Такий підхід до визначення фінансового механізму відображає внутрішню організацію функціонування фінансів підприємств.

Фінансовий механізм відповідно до системного підходу визначається як сукупність методів i форм, інструментів, прийомів і важелів впливу на стан та розвиток підприємства. Цей підхід відображає зовнішню дію функціонування фінансів підприємств, характеризує фінанси як вирішальний чинник впливу апарату управління на економічний стан підприємства. Завдяки такому аспекту дослідження фінансового механізму з'являється можливість чітко визначити його складові та структуру.

Деякий час перша концепція щодо визначення фінансового механізму як способу організації фінансових відносин, який складається 3 елементів та інструментів впливу, в вітчизняній економічній літературі була пріоритетною. До сьогодні ії підтримують Л.А. Дробозіна, В.М. Родіонова, Л.Л. Осипчук та ін. В той же час ототожнення організації фінансових відносин і фінансового механізму є необгрунтованим, особливо в умовах розвитку ринкової економіки. Лише внутрішнє управління фінансами стає недостатнім, а тому потребує розвитку другий підхід. Однак і останній має суттєві недоліки, основними 3 яких є відсутність взаємодії підсистем та блоків, розмежування сфери функціонування та цілеспрямованої дії елементів механізму. Сьогодні таке розуміння можна знайти у В.Д. Базилевича і Л.О. Баластрика [2, с. 18], В.М. Опаріна [6, с. 55], О.Р. Романенко, С.Я. Огородника, B.I. Аранчія та ін. Однак зауважимо, що більшість цих економістів розглядають фінансовий механізм у контексті фінансів держави.

Відзначаючи неповноту дефініцій фінансового механізму, О.М. Ковалюк [5, с. 54] пропонує розглядати фінансовий механізм як систему фінансових форм, методів, важелів та інструментів, які використовують у фінансовій діяльності держави і підприємств за відповідного нормативного, правового та інформаційного їхнього забезпечення, а також за відповідної фінансової політики на мікро- і макрорівні. Однак в даному визначенні чітко не встановлено цілі дії механізму. Відповідь можна знайти у А.М. Поддєрьогіна, який визнає, що фінансовий механізм реалізується з метою оптимізації впливу фінансів на кінцеві результати діяльності підприємства [8, с. 15].

Таким чином, враховуючи принципи організації фінансів в умовах ринкової економіки та трансформаційних процесів, доцільним $є$ удосконалення методології формування та реалізації фінансового механізму стійкого розвитку підприємств. Пропонуємо розширити концептуальний підхід до визначення механізму за рахунок включення комплексного, програмно-цільового та критеріального підходів.

Якщо системний підхід дозволяє визначити структуру фінансового механізму, виявити роль кожного елементу в загальній системі, взаємозв'язок, вплив системи на елементи і навпаки; процесний розробити дії щодо реалізації функцій управління фінансовою діяльністю, то програмно-цільовий підхід відображає формування механізму відповідно цільовим програмам розвитку підприємств для досягнення оперативних, тактичних, стратегічних цілей із врахуванням впливу внутрішніх та зовнішніх чинників; комплексний - поєднує різні підходи в загальну систему управління фінансами підприємств; критеріальний - забезпечує розробку індивідуальних оціночних критеріїв ефективності функціонування фінансового механізму по окремих підрозділах, підприємству в цілому з метою реалізації стимулюючої функції цього механізму.

Зауважимо, що провідні західні вчені фінансовий механізм не виділяють як відокремлений об'єкт дослідження, але всебічно і грунтовно вивчають фінансові методи впливу на підприємство, державу i суспільство.

Стійкість промислового підприємства залежить від сукупності внутрішніх і зовнішніх чинників, які наведено на рис. 1 .

Найважливішою зі складових стійкого функціонування та розвитку промислового підприємства $\epsilon$ саме фінансова складова, а отже, вихідною базою для управління фінансовою стійкістю підприємства $є$ його фактичний фінансовий стан. 


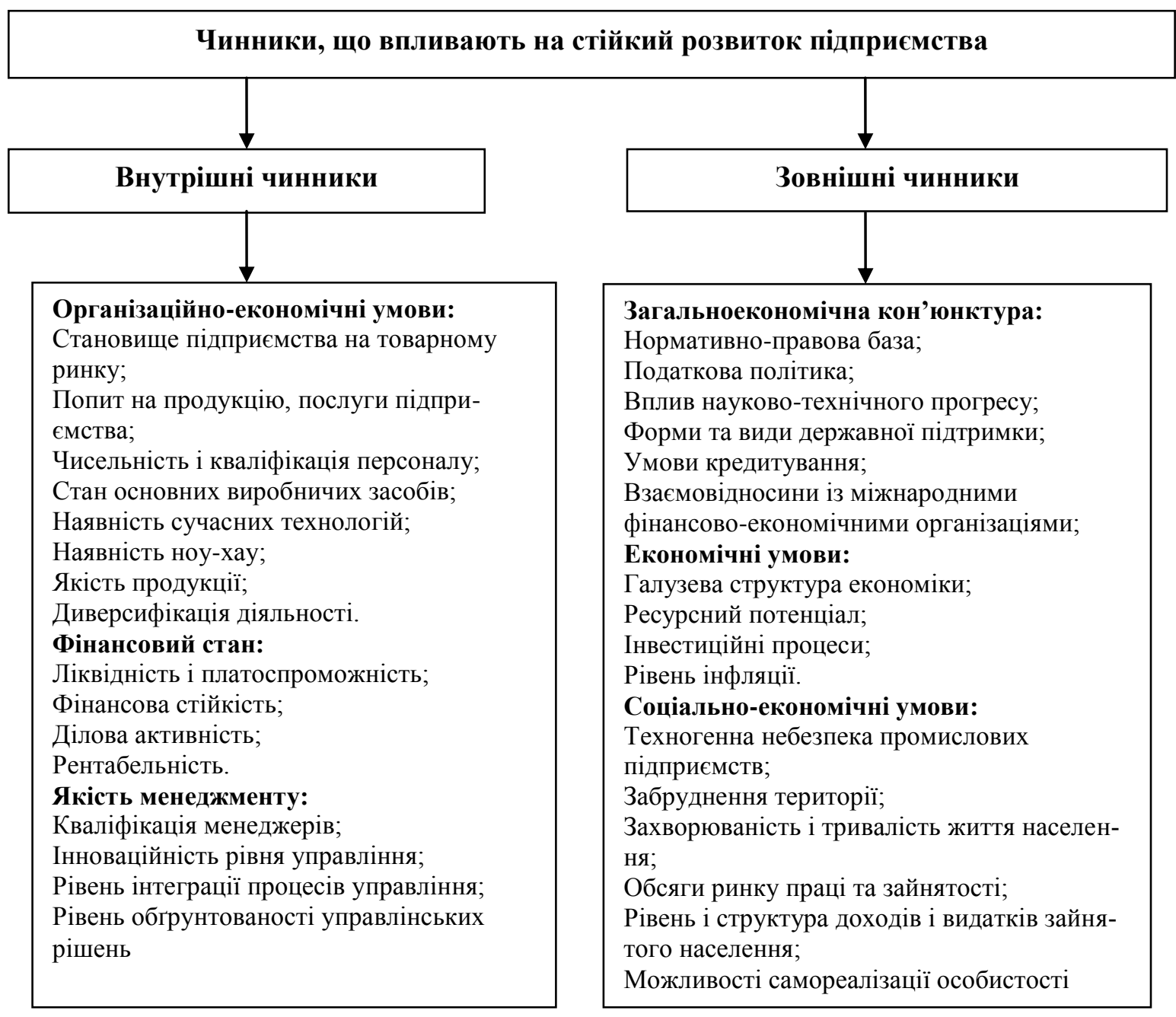

Рис. 1. Система чинників стійкого розвитку підприємства [авторська розробка]

Висновки та перспективи подальших досліджень. Таким чином, можна узагальнити, що механізм збалансування фінансів підприємств - це сукупність взаємопов'язаних і взаємообумовлених форм, методів, інструментів, важелів дотримання правильних пропорцій у русі фінансових потоків підприємства по всіх фазах циклу кругообігу фінансових ресурсів (формування, розподілу, використання) у відповідності до законодавчого, нормативного, інформаційного, кадрового, технічного забезпечення 3 метою реалізації стратегії стійкого зростання в поточному та перспективному періодах. Якщо визначити фінанси як об'єкт управління, то реалізація механізму здійснюється через сукупність управлінських функцій, зокрема прогнозування, планування, стимулювання, координування, організацію, регулювання, контроль. Відповідно, організаційним забезпеченням дії механізму є планування, прийняття та реалізація фінансових рішень, контроль, аналіз відхилень.

Подальші дослідження будуть спрямовані на проблеми управління фінансовою стійкістю підприємства.

\section{Література}

1. Артус М. М. Фінансовий механізм в умовах ринкової економіки /М. М. Артус // Фінанси України. 2005. - № 5. - С. 54-59.

2. Базилевич В. Д. Державні фінанси: [навч. посіб.] / В. Д. Базилевич, Л. О. Баластрик; за заг. ред. В. Д. Базилевича. - К.: Ari, 2004. - 363 с.

3. Балабанов А. И. Финансы: [учеб. пособие] / А. И. Балабанов, И. Т. Балабанов. - СПб.: Питер, 2002. $188 \mathrm{c}$.

4. Ковалев В. В. Финансовый анализ: методы и процедуры / В. В. Ковалев. - М.: Финансы и статистика, 2002. $-560 \mathrm{c}$. 
5. Ковалюк О. М. Методологічні основи фінансового механізму / О. М. Ковалюк // Фінанси України. 2003. - № 4. - C. 54.

6. Опарін В. М Фінанси (загальна теорія): [навч. посібник] / В. М. Опарін. - [2-ге вид., доп. і перероб.]. - К.: КНЕУ, 2001. - 240 c.

7. Тарасевич Н. В. Види та значення комплексної оцінки фінансового стану банку / Н. В. Тарасевич // Вісник соціально-економічних досліджень. Збірник наукових праць. - 2013. - № 4 (51). - С. 361-365.

8. Фінанси підприємств: [підручник] / За ред. Поддєрьогіна А. М. - К.: КНЕУ, 2004. - 546 с.

9. Шеремет А. Д. Методика финансового анализа коммерческих организаций / А. Д. Шеремет. - [2-е изд., перераб. и доп.]. - М. : ИНФРА-М, 2010. - 208 с.

10. Branch B. The Cost of Bankruptcy / B. Branch // International Review of Financial Analysis. - 11. 2002. - P. 39-57.

Стаття надійшла 20.04.2016

Стаття прийнята до друку 4.05.2016

Тарасова Е.В.

кандидат экономических наук, доцент кафедра учета и аудита

Одесская национальная академия пищевых технологий ул. Канатная, 112, г. Одесса, Украина, 65039

E-mail: tarasova2k@yandex.ua

\section{ФИНАНСОВЫЙ МЕХАНИЗМ УСТОЙЧИВОГО РАЗВИТИЯ ПРЕДПРИЯТИЯ}

В статье исследуется роль фринансового механизма обеспечения устойчивого развития предприятия, обосновывается необходимость обеспечения сбалансированности между целями предприятия и условиями внешней и внутренней среды. Эта сбалансированность характеризуется определенными значениями показателей финансового состояния предприятия и зависит от совокупности факторов окружающей среды. Определены составляющие подсистемы финансового механизма, обеспечивающие устойчивое развитие предприятия.

Рассмотрены существующие методологические подходы к организации фринансов. Предлагается расширить концептуальный подход к определению финансового механизма за счет включения комплексного, программно-целевого и критериального подходов.

Исследована система внутренних и внешних фракторов устойчивого развития предприятия. Сделан вывод о том, что организационным обеспечением действия финансового механизма является планирование, принятие и реализация финансовых решений, контроль, анализ отклонений.

Ключевые слова: финансовый механизм; финансовая устойчивость; финансовые рычаги; финансовые отношения; фринансовые методы.

Tarasova O.V.

$\mathrm{PhD}$ in Economics, Associate Professor

Department of Accounting and Auditing

Odessa National Academy of Food Technologies

st. Kanatna, 112, Odessa, Ukraine, 65039

E-mail: tarasova2k@yandex.ua

\section{FINANCIAL MECHANISM OF SUSTAINABLE DEVELOPMENT OF THE ENTERPRISE}

\footnotetext{
Abstract. The article examines the role of the financial mechanism of sustainable development of the enterprise, the necessity to ensure a balance between the objectives of the enterprise and conditions of external and internal environment. This balance is characterized by certain values of indicators of the
} 
company's financial condition and depends on a combination of environmental factors. The components of the subsystem of the financial mechanism, to ensure sustainable development of the company.

The existing methodological approaches to the finance organization. It is proposed to expand the conceptual approach to the definition of a financial mechanism to include a comprehensive, programoriented approach and a criterion.

A system of internal and external factors of sustainable development of the enterprise. Organizational maintenance of the financial mechanism of action is the planning, adoption and implementation of financial decisions, control, analysis of variance.

Keywords: the financial mechanism; financial stability; financial leverage; financial ratios; financial methods.

\section{References}

1. Aptus, M. M. (2005). Finansovyi mekhanizm v umovakh rynkovoi ekonomiky. Finansy Ukrainy, 5, 54-59.

2. Bazylevych, V. D., \& Balastryk, L. O. (2004). Derzhavni finansy. K.: Ari.

3. Balabanov, A. Y., \& Balabanov, Y. T. (2002). Fynansu. Pyter: SPb.

4. Kovalev, V. V. (2002). Fynansovui analyz: Metodu y protseduru. M.: Fynansu y statystyka.

5. Kovaliuk, O. M. (2003). Metodolohichni osnovy finansovoho mekhanizmu. Finansy Ukrainy, 4, 54.

6. Oparin, V. M. (2001). Finansy. K.: KNEU.

7. Tarasevych, N. V. (2013). Vydy ta znachennia kompleksnoi otsinky finansovoho stanu banku. Visnyk Sotsialno-ekonomichnykh Doslidzhen, 4 (59), 361-365.

8. Poddierohina, A. M. (2004). Finansy pidpryiemstv. K.: KNEU.

9. Sheremet, A. D. (2010). Metodyka fynansovoho analyza kommercheskykh orhanyzatsyi. M.: YNFRA-M.

10. Branch, B. (2002). The Cost of Bankruptcy. International Review of Financial Analysis, 11, 39-57. 